\title{
THE SILENT SPREAD OF PORCINE BOCAVIRUS IN CROATIAN PIGS: SHOULD WE BE CONCERNED?
}

\author{
Tomislav Keros ${ }^{1}$, Lorena JemeršIĆ ${ }^{1}$, Ivan TOPLAK ${ }^{2}$ and Jelena PRPIĆ ${ }^{1 *}$ \\ ${ }^{1}$ Department of Virology, Croatian Veterinary Institute, Savska cesta 143, \\ HR-10 000 Zagreb, Croatia; ${ }^{2}$ Institute of Microbiology and Parasitology, Virology Unit, \\ Veterinary Faculty, University of Ljubljana, Ljubljana, Slovenia
}

(Received 20 March 2017; accepted 6 November 2017)

\begin{abstract}
A survey was conducted to evaluate the presence and prevalence of Porcine Bocavirus ( $\mathrm{PBoV}$ ) in Croatian domestic pigs by means of PCR targeting the NS1 gene fragment of PBoV. This study included testing of faecal samples collected from 10 small commercial farms and 11 small backyard holdings in Croatia. The presence of PBoV was confirmed by PCR in 24 out of 57 composite faecal samples from small commercial farms and in 12 out of 43 composite faecal samples from small backyard holdings. The PCR products of 18 positive samples were sequenced for genotyping. PBoV sequences grouped into the PBoV-a, PBoV-b and PBoV-c groups with $90.81 \%$ to $99.25 \%$ nucleotide identity. All Croatian $\mathrm{PBoV}$ sequences showed a high nucleotide and amino acid identity with PBoV sequences from China and Hong Kong, the United States, Sweden, and Slovenia. These results clearly show that $\mathrm{PBoV}$ is circulating among the domestic pig population in Croatia.
\end{abstract}

Key words: Domestic pigs, Croatia, Porcine Bocavirus, phylogenetic analysis, PCR

The family Parvoviridae is classified into two subfamilies: the subfamily Parvovirinae, which infects vertebrates, and the subfamily Densovirinae, which infects arthropods. Based on a report published by the International Committee on Taxonomy of Viruses (ICTV), the subfamily Parvovirinae is divided into eight genera: Amdoparvovirus, Aveparvovirus, Bocaparvovirus, Copiparvovirus, Dependoparvovirus, Erythroparvovirus, Protoparvovirus and Bocaparvovirus (Tattersall et al., 2005; https://talk.ictvonline.org/taxonomy/). Bocaviruses are isometric, non-enveloped, autonomously replicating, single-stranded DNA viruses containing a genome of approximately $5 \mathrm{~kb}$ in length. According to some previous findings, bocaviruses are involved in the development of respiratory and enteric infections in humans and animals (Chen et al., 1986; Chen et al., 1988;

*Corresponding author; E-mail: balatinec@veinst.hr; Phone: 00385 (1) 6123-675; Fax: 00385 (1) 6190-841 
Schwartz et al., 2002; Allander et al., 2005; Manteufel and Truyen, 2008; Chen et al., 2010; Kapoor et al., 2010a, b).

The genus Bocavirus comprises four members: Bovine Parvovirus (BPV), Canine Minute Virus (CnMV), Human Bocavirus (HBoV) and Gorilla Bocavirus $(\mathrm{GBoV})$, and it has gained special attention because of $\mathrm{HBoV}$, which causes respiratory diseases in children. In the field of veterinary medicine, BPV and CnMV were discovered in the $1960 \mathrm{~s}$ and they share about $40 \%$ sequence identity (Schwartz et al., 2002). Like other members of the Parvoviridae family, bocaviruses contain a non-structural protein (NS1) and the VP1/VP2 structural protein. However, the non-structural NP1 protein encoded by an open reading frame (ORF) in the middle of the genome is a unique structure characterising bocaviruses, which is absent in most members of the Parvoviridae family (Allander et al., 2005) A novel porcine boca-like virus (PBo-likeV) was discovered in 2009 in Swedish pigs with postweaning multisystemic wasting syndrome (PMWS) using random amplification and large-scale sequencing technology (Blomström et al., 2009). Subsequent studies indicated a high prevalence of this novel PBoV in weaning piglets with respiratory tract symptoms. $\mathrm{PBoV}$ has also been detected in healthy pigs in China (Zhai et al., 2010). The grouping of PBoV is confusing in different reports when different regions of the genome (whole genome, NS1, VP1 or NP1) were used for phylogenetic analysis, which makes the differentiation of novel PBoVs difficult (Liu et al., 2014). Based on the non-structural (NS1) gene, PBoV is classified into six different clades, from PBoV-a to PBoV-f (Liu et al., 2014). PBoV has not been successfully cultured and no serological tests are available for its detection, and only conventional PCR assays have been described (Zhai et al., 2010). In contrast to conventional assays, real-time PCR offers rapid results with potentially increased sensitivity and specificity of detection. It is also less prone to false positive results and is more amenable to the quantitative estimation of viral load.

In this study, a survey on the presence and prevalence of $\mathrm{PBoV}$ in different parts of Croatia was conducted by real-time PCR, and selected PBoVpositive samples were sequenced in the NS1 gene and compared with reference sequences retrieved from the GenBank database.

\section{Materials and methods}

\section{Specimen collection}

Composite faecal samples were collected from 10 small commercial farms (ranging from 10 to 1000 sows in size) and 11 small backyard holdings (up to 5 sows) in 2012. In this study, 57 composite faecal samples from small commercial pig farms and 43 composite faecal samples from small backyard holdings were tested for the presence of $\mathrm{PBoV}$. Holdings were selected to ensure a representa- 
tive sampling throughout Croatia from 10 counties (Osijek-Baranja, VukovarSrijem, Brod-Posavina, Virovitica-Podravina, Zagreb, Krapina-Zagorje, Međimurje, Karlovac, Istra and Šibenik-Knin) shown in Table 1. The pigs included in the present study were healthy and did not exhibit signs of gastrointestinal disease or other general signs of infectious diseases. Each composite sample consisted of at least five subsamples taken from different parts of the randomly chosen unit where pigs were kept in a group of up to 20 animals depending on pig category. These samples were also distributed by age, and therefore they were collected from nursing, post-weaning and finisher pigs, gilts, sows and boars. Faecal samples were collected in sterile containers, transported and stored as blood samples or deep frozen if not processed immediately.

Table 1

Categories of pigs positive $(+)$ and negative $(-)$ for Porcine Bocavirus in the different counties tested

\begin{tabular}{|c|c|c|c|c|c|c|}
\hline \multirow[b]{2}{*}{ Counties } & \multicolumn{6}{|c|}{ Categories of pigs } \\
\hline & $\begin{array}{c}\text { Suckling } \\
\text { pigs }\end{array}$ & $\begin{array}{c}\text { Weaned } \\
\text { pigs }\end{array}$ & $\begin{array}{l}\text { Fattening } \\
\text { pigs }\end{array}$ & Gilts & Sows & Boars \\
\hline Osijek-Baranja & + & + & + & + & + & - \\
\hline Vukovar-Srijem & - & + & + & - & + & + \\
\hline Brod-Posavina & + & - & + & + & - & - \\
\hline Virovitica-Podravina & - & - & + & - & - & - \\
\hline Zagreb & - & + & + & - & - & - \\
\hline Krapina-Zagorje & + & + & + & - & - & - \\
\hline Međimurje & + & + & + & + & + & + \\
\hline Istra & + & - & - & - & + & - \\
\hline Karlovačka & - & - & - & - & - & - \\
\hline Šibenik-Knin & + & - & + & - & + & - \\
\hline
\end{tabular}

\section{Sample preparation and viral DNA purification}

The faecal samples were resuspended in phosphate-buffered saline (PBS; $\mathrm{pH} 7.4$ ) in order to obtain $20 \% \mathrm{w} / \mathrm{v}$ faecal suspensions which were then vortexed for $1 \mathrm{~min}$ and centrifuged for $15 \mathrm{~min}$ at $1000 \mathrm{~g}$. Supernatants were further centrifuged for $3 \mathrm{~min}$ at 18,000 $\mathrm{g}$ and used for subsequent viral DNA purification. An amount of $200 \mu \mathrm{l}$ of each faecal supernatant sample was used for viral DNA purification by using the QIAamp ${ }^{\circledR}$ DNA Mini kit (Qiagen, Hilden, USA) according to the manufacturer's instructions. The DNA samples purified from faecal samples were stored at $-80{ }^{\circ} \mathrm{C}$ until needed. 


\section{PCR protocols and sequencing}

To identify PBoV DNA carriers, a real-time PCR protocol (Li et al., 2011) for detecting a fragment within NP1 was carried out. All positive samples were re-tested by a PCR protocol previously described (Liu et al., 2014) for detecting a conserved region of the NS1 gene. The amplification procedure for the NS1 region was as follows: denaturation at $94{ }^{\circ} \mathrm{C}$ for $2 \mathrm{~min}$; incubation at $94{ }^{\circ} \mathrm{C}$ for $20 \mathrm{~s}, 55^{\circ} \mathrm{C}$ for $30 \mathrm{~s}$, and $72{ }^{\circ} \mathrm{C}$ for $1 \mathrm{~min}(35 \mathrm{cycles})$; and incubation at $72{ }^{\circ} \mathrm{C}$ for $7 \mathrm{~min}$. PCR products were separated by agarose gel electrophoresis in 1.5\% agarose gel stained with a fluorescent dye (GelStar, Lonza) and visualised by UV transillumination. Slovenian PBoV-positive samples, kindly provided by Dr. Ivan Toplak (Veterinary Faculty, Ljubljana, Slovenia) were used as positive controls. Negative controls were aliquots of ultra-pure water. All samples containing PBoV DNA detectable in a lower cycle threshold value of 40 were conducted to sequencing. PCR products were purified (Wizard SV gel) by PCR Clean up system (Promega, Madison, USA) and sequenced by Macrogen Inc. (Amsterdam, Netherlands). Phylogenetic grouping and clustering of all obtained sequences was based on comparison with sequences retrieved from the GenBank and similar sequences obtained using the BLAST algorithm (http://www.ncbi.nlm.nih.gov). Sequences were aligned by ClustalW 2.0 (Thompson et al., 1997) and analysed using MEGA 5 (Tamura et al., 2011), whereas the trees were generated using the neighbour-joining method applying the Kimura 2-parameter evolutionary model.

\section{Results}

\section{$D N A$ prevalence results obtained by real-time $P C R$}

To obtain the prevalence, a farm was considered positive if any composite faecal sample yielded a positive PCR result. A high prevalence $(10 / 10,100 \%)$ was found in pigs from small commercial farms, and a lower prevalence $(5 / 11$, $45.45 \%$ ) was observed in animals from small backyard holdings. The presence of PBoV was confirmed in $24(42.1 \%)$ out of 57 composite faecal samples from small commercial pig farms and in $12(27.9 \%)$ out of 43 composite faecal samples from small backyard holdings. PBoV was present in all tested counties in Croatia, with the exception of Karlovačka county.

\section{Sequencing results}

The amplification of a 680-bp fragment of the NS1 gene from 18 selected PBoV-positive samples resulted in clear PCR products with the expected molecular size. In each amplification experiment, a clear amplification signal was detected when using the positive control and no amplification was obtained when using no-template controls. 


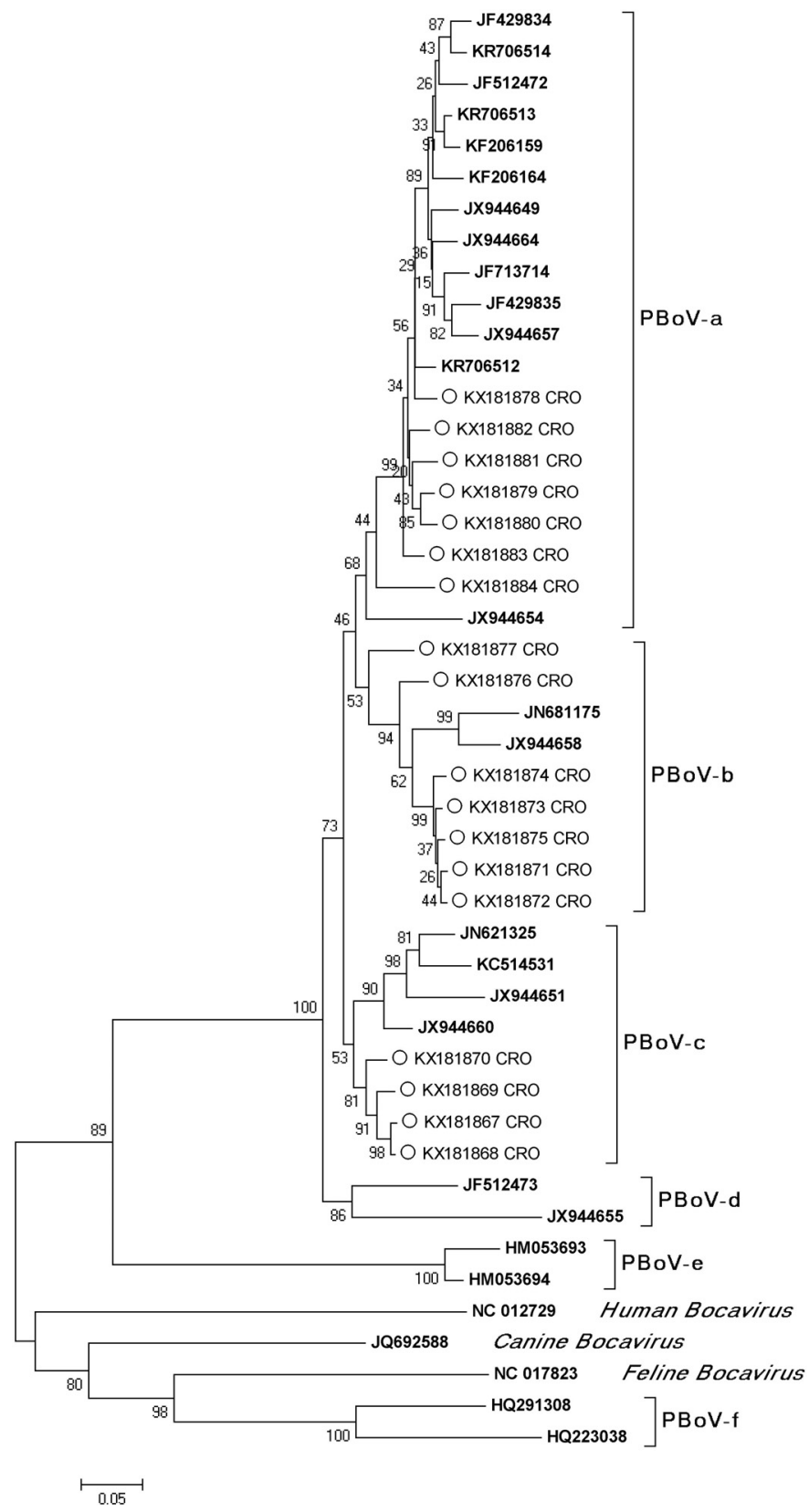

Fig. 1. Neighbour-joining phylogenetic tree obtained by the analysis of the partial NS1 gene region of PBoV strains derived from domestic pig samples (circle) in Croatia. Genetic distances were calculated using the Kimura two-parameter method. Genotype reference sequences (bold) were adopted from Liu et al. (2014). HBoV, CnMV and feline bocavirus sequences were used as outgroups. Bootstrap values are presented next to tree nodes. The bar represents 0.05 nucleotide substitution per site 


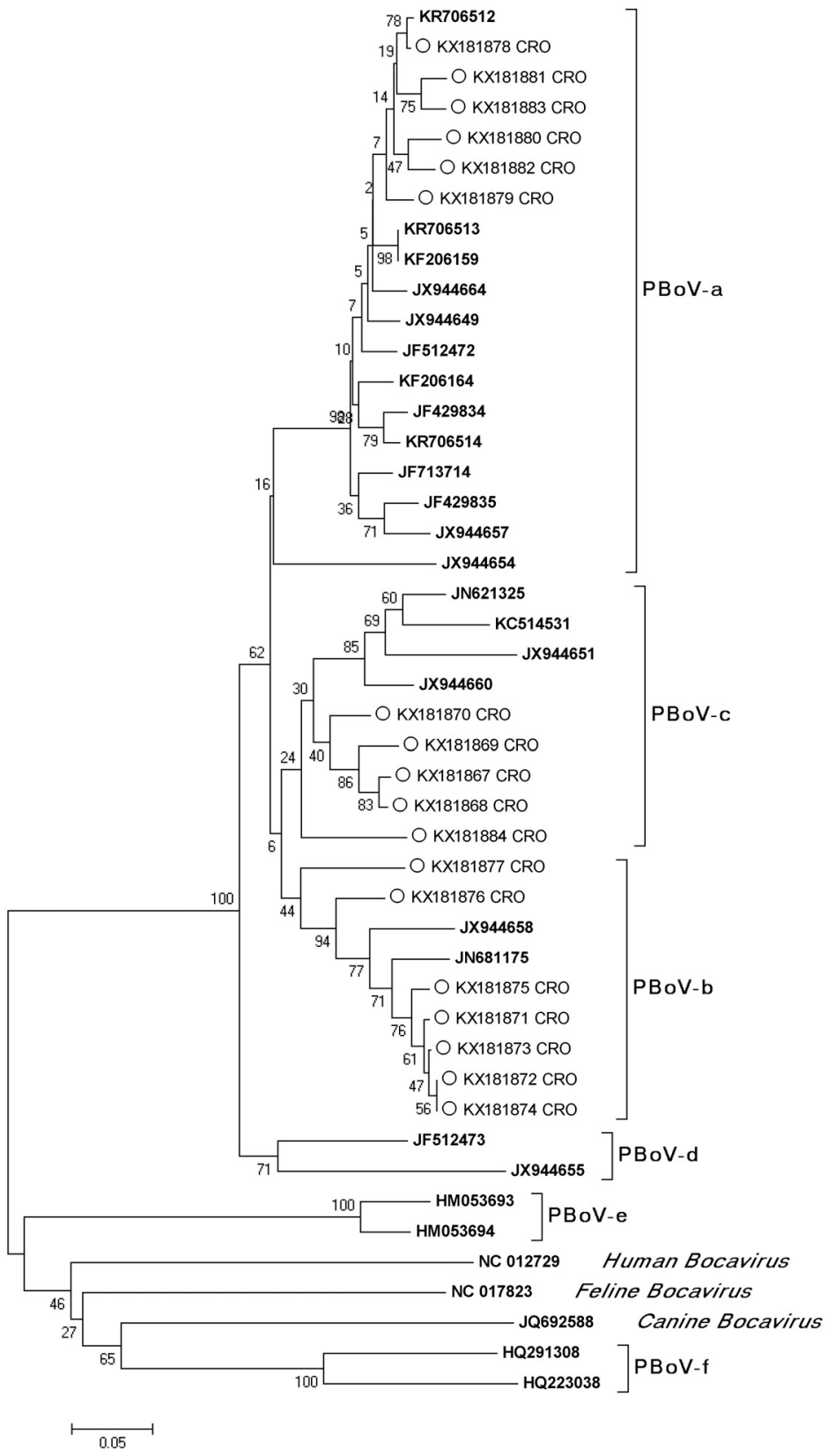

Fig. 2. Neighbour-joining phylogenetic tree constructed based on partial NS1 amino acid sequences of reference PBoV (bold) and $\mathrm{PBoV}$ from Croatian domestic pigs (circle). Genetic distances were calculated using the p-distance method. Genotype reference sequences (bold) were adopted from Liu et al. (2014). HBoV, CnMV and feline bocavirus sequences were used as outgroups. Bootstrap values are presented next to tree nodes. The bar represents 0.05 amino acid substitution per site 


\section{Sequence analysis}

The phylogenetic relationship analyses based on NS1 amplicons of $636 \mathrm{bp}$ confirmed that all sequences obtained from domestic pigs were PBoV specific (Fig. 1). According to the classification proposed by Liu et al. (2014), all 18 Croatian PBoV sequences (GenBank accession numbers KX181867-KX181884) were grouped into the PBoV-a, PBoV-b and PBoV-c groups. By mutual comparison of different Croatian isolates, $90.81 \%$ to $97.89 \%$ nucleotide identity was found in group $\mathrm{PBoV}-\mathrm{a}, 91.41 \%$ to $98.94 \%$ in group $\mathrm{PBoV}-\mathrm{b}$ and $96.38 \%$ to $99.25 \%$ in group PBoV-c. A similar amino acid sequence alignment result showed that all Croatian PBoV sequences grouped into the PBoV-a, PBoV-b and PBoV-c groups (Fig. 2). Amino acid identity of the partial NS1 protein sequence varied from $85.52 \%$ to $95.02 \%$ for Croatian $\mathrm{PBoV}$-a, from $94.12 \%$ to $97.74 \%$ for Croatian PBoV-b and from $93.21 \%$ to $98.19 \%$ for Croatian PBoV-c group sequences. All Croatian PBoV sequences showed high nucleotide and amino acid identity with PBoV sequences from Slovenia (KR706512, 96.32\%) and China (JX944654, 88.23\%; JX944658, 89.71\% and JX944660, 92.35\%).

\section{Discussion}

Bocaviruses are emerging pathogens that cause various diseases in humans and animals. HBoV was first described in 2005 as the causative agent of respiratory disease in children (Allander et al., 2005). Animal bocaviruses CnMV and BPV were described in the 1960s (Lau et al., 2008; Manteufel and Truyen, 2008). PBoV was recorded in 2009 in Swedish pigs with PMWS (Blomström et al., 2009). PBoV has not been successfully cultured and no serological tests are available for its detection, and only conventional PCR assays have been described (Zhai et al., 2010).

The pig population of Croatia contains a rather low number of sows (there were about 100,000 sows in 2016 according to the Croatian Agricultural Agency; Mahnet et al., 2017). This led to an increase of import of pigs and pig products from EU countries. Furthermore, the export of pigs and pig products from Croatia to EU countries has been banned since 2006 when an outbreak of classical swine fever occurred. Intensive pig production is mainly practised in the continental region of Croatia. Small breeding farms are present in all regions of Croatia and the pig products are mostly used for the owners' own consumption or sold locally. Therefore, all pathogens within a farm may cause economic losses to the owners. Since PBoV may be a cause of economic loss to the pig industry, a survey was conducted to determine its presence in the Croatian pig production sector. Our investigation determined the prevalence of $\mathrm{PBoV}$ among different pig herds in Croatia in all counties included in the survey, both in small commercial pig farms $(100 \%)$ and in small backyard holdings $(45 \%)$. PBoV was also 
present in all age groups regardless of the type of breeding conditions. Most of the positive samples were found within the fattening pigs age group independently of the county, whereas boars proved to be the least infected group. Interestingly, no disease signs were reported in the tested pigs, probably due to the absence of secondary infections or the good immunological status of the herds. All Croatian $\mathrm{PBoV}$ sequences showed high nucleotide and amino acid identity with PBoV sequences from the neighbouring Slovenia (KR706512) and from China (JX944654, JX944658 and JX944660). Our results indicate that PBoV might have been introduced by imported pigs and that high pig density is likely to increase its transmission.

\section{Acknowledgements}

The authors warmly thank Dragan Brnić DVM, PhD (Croatian Veterinary Institute, Zagreb), who kindly provided swine samples.

\section{References}

Allander, T., Tammi, M. T., Eriksson, M., Bjerkner, A., Tiveljung-Lindell, A. and Andersson, B. (2005): Cloning of a human parvovirus by molecular screening of respiratory tract samples. Proc. Nat. Acad. Sci. USA 102, 12891-12896.

Blomström, A. L., Belák, S., Fossum, C., McKillen, J., Allan, G., Wallgren, P. and Berg, M. (2009): Detection of a novel porcine boca-like virus in the background of porcine circovirus type 2 induced postweaning multisystemic wasting syndrome. Virus Res. 146, $125-129$.

Chen, A. Y., Cheng, F., Lou, S., Luo, Y., Liu, Z., Delwart, E., Pintel, D. and Qiu, J. (2010): Characterization of the gene expression profile of human bocavirus. Virology 403, 145-154.

Chen, K. C., Shull, B. C., Moses, E. A., Lederman, M., Stout, E. R. and Bates, R. C. (1986): Complete nucleotide sequence and genome organization of bovine parvovirus. J. Virol. 60, 1085-1097.

Chen, K. C., Shull, B. C., Lederman, M., Stout, E. R. and Bates, R. C. (1988): Analysis of the termini of the DNA of bovine parvovirus: demonstration of sequence inversion at the left terminus and its implication for the replication model. J. Virol. 62, 3807-3813.

Kapoor, A., Mehta, N., Esper, F., Poljsak-Prijatelj, M., Quan, P. L., Qaisar, N., Delwart, E. and Lipkin, W. I. (2010a): Identification and characterization of a new bocavirus species in gorillas. PLoS ONE 5, e11948.

Kapoor, A., Simmonds, P., Slikas, E., Li, L., Bodhidatta, L., Sethabutr, O., Triki, H., Bahri, O., Oderinde, B., Baba, M., Bukbuk, D., Besse, J., Bartkus, J. and Delwart, E. (2010b): Human bocaviruses are highly diverse, dispersed, recombination prone, and prevalent in enteric infections. J. Infect. Dis. 201, 1633-1643.

Lau, S. K., Woo, P. C., Tse, H., Fu, C. T., Au, W. K., Chen, X. C., Tsoi, H. W., Tsang, T. H., Chan, J. S., Tsang, D. N., Li, K. S., Tse, C. W., Nq, T. K., Tsang, O. T., Zheng, B. J., Tam, S., Chan, K. H., Zhou, B. and Yuen, K. J. (2008): Identification of novel porcine and bovine parvoviruses closely related to human parvovirus 4. J. Gen. Virol. 89, 1840-1848.

Li, B., Xiao, S., Ma, J., Liu, Y., Mao, L., Wen, L., Mao, A., Zhang, X., Ni, Y., Guo, R., Zhou, J., Yu, Z., Lv, L., Wang, X., Fang, L., Chen, H. and He, K. (2011): Development of a novel 
TaqMan-based real-time PCR assay for the detection of porcine boca-like virus (PBolikeV). Virol. J. 8, 357.

Liu, M., Li, Y., Sun, D., Xia, Y., Huang, J. and Guo, L. (2014): Detection and genetic analysis of porcine bocavirus in different swine herds in north central China. Sci. W. J. 2014, 947084.

Mahnet, Ž., Klišanić, V., Lubina Malus, N., Prpić, V., Uzelac, M. and Hunjak, M. (2017): Pig Breeding, Annual Report for 2016 [in Croatian]. Croatian Agricultural Agency, Križevci, Croatia. p. 8.

Manteufel, J. and Truyen, U. (2008): Animal bocaviruses: a brief review. Intervirol. 51, 328-334.

Schwartz, D., Green, B., Carmichael, L. E. and Parrish, C. R. (2002): The canine minute virus (minute virus of canines) is a distinct parvovirus that is most similar to bovine parvovirus. Virology 302, 219-223.

Tamura, K., Peterson, D., Peterson, N., Stecher, G., Nei, M. and Kumar, S. (2011): MEGA5: molecular evolutionary genetics analysis using maximum likelihood, evolutionary distance, and maximum parsimony methods. Mol. Biol. Evol. 28, 2731-2739.

Tattersall, P., Bergoin, M., Bloom, M. E., Brown, K. E., Linden, R. M., Muzyczka, N., Parrish, C. R. and Tijsses, P. (2005): Family Parvoviridae. In: Fauquet, C. M., Mayo, M. A., Maniloff, J., Desselberger, U. and Ball, L. A. (eds) Virus Taxonomy: Classification Nomenclature of Viruses. The Eighth Report of the International Committee on the Taxonomy of Viruses, Elsevier Academic Press, London, UK. pp. 353-369.

Thompson, J. D., Gibson, T. J., Plewniak, F., Jeanmougin, F. and Higgins, D. G. (1997): The CLUSTAL X windows interface: flexible strategies for multiple sequence alignment aided by quality analysis tools. Nucleic Acids Res. 25, 4876-4882.

Zhai, S., Yue, C., Wei, Z., Long, J., Ran, L., Lin, T., Deng, Y., Huang, L., Sun, L., Zheng, H., Gao, F., Zheng, H., Chen, S. and Yuan, S. (2010): High prevalence of a novel porcine bocavirus in weanling piglets with respiratory tract symptoms in China. Arch. Virol. 155, 1313-1317. 